\title{
Bacteriological Testing of Milk Samples Suspected of Sub-Clinical Mastitis: A Case Study
}

\author{
Subha Ganguly \\ Associate Professor, Department of Veterinary Microbiology, ARAWALI VETERINARY \\ COLLEGE (Affiliated with Rajasthan University of Veterinary and Animal Sciences, Bikaner) \\ Rajasthan, India
}

\begin{abstract}
There are two forms of mastitis viz., clinical and sub-clinical forms. The present article reports the microbiological investigation of a clinical case of mastitis in dairy cattle by following the proper dose regimen and schedule of recommended antibiotics for treatment. Mastitis is usually caused by bacteria that invade the udder, multiply and produce toxins which are harmful to the mammary gland. It remains the most economically important disease of dairy industries around the world producing great economic loss to farmers.
\end{abstract}

Keywords: Antibiotics, Antibiogram, Mastitis

\section{INTRODUCTION}

The indiscriminate and injudicious administration of antibiotics and irrational treatment of bovine mastitis with different antibiotics have invited serious complications like multiple drug resistance. Mastitis is characterized by the chronic inflammation of the mammary gland of cattle and can have infectious and non-infectious etiologies. It is characterized by physical, chemical and usually bacteriological changes in the milk and pathological changes in the glandular tissue of the udder and affects quality and quantity of milk. Till date different types of antibiotics have been tried against the pathogens in bovine mastitis with or without identification and drug sensitivity testing. ${ }^{[1-5]}$ The present study was conducted to test whether the suspected test milk samples were infected from subclinical mastitis and the antibiotics/ antibacterial drugs which may prove effective for its treatment.

\section{Materials AND Methods}

Four (04) milk samples collected from the suspected four quarters of the udder of a crossbred cattle exhibiting clinical symptoms of mastitis were produced at the Teaching Veterinary Clinical Complex (T.V.C.C.) of Arawali Veterinary College. The collected milk samples were then forwarded to the Department of Veterinary Microbiology during March, 2017 for bacteriological investigation and reporting. The collected milk samples looked apparently normal in appearance.

The milk samples were examined bacteriologically ${ }^{[6]}$ for the colony characteristics by nutrient agar plate culturing. Bacterial staining was done by Gram's Method ${ }^{[7]}$. The antibiotic sensitivity test was performed as per Kirby-Bauer antibiotic disc diffusion assay method on Mueller-Hinton agar plates with certain modifications ${ }^{[8-10]}$ using antibiotic discs provided by the supplier (Microbes \& Diagnostic $\&$ Research Centre, Ahmedabad, India).The concentration of antibiotic in each filter paper disc was as per the specification of the manufacturer required for laboratory purpose. Incubation of the petridishes layered with the agar containing antibiotic discs was done at $37^{\circ} \mathrm{C}$ for $24 \mathrm{~h}$ in a B.O.D. incubator installed at the department.

\section{RESUlTS AND DISCUSSION}

The overnight incubated nutrient broth cultures of the milk samples were subjected to spread plate culture on Nutrient agar media plates. After incubation at $37^{\circ} \mathrm{C}$ for $24 \mathrm{~h}$ it revealed the presence of circular, convex, glistening colonies with full regular edges on the agar media. Grams' staining revealed the presence of Gram positive cocci arranged in the form of clusters when examined under the high power magnification of the compound microscope. The bacteria was bacteriologically determined to be grouped under Staphylococcus spp. ${ }^{[6-10]}$ 
Antibiotic disc diffusion assay revealed the bacterial isolates to be highly sensitive to the minimum inhibitory concentration (MIC) of the antibiotics namely, ceftriaxone $(30 \mathrm{mcg})$, tetracycline $(30 \mathrm{mcg})$ and gentamicin $(10 \mathrm{mcg})$ with moderate sensitivity to amoxicillin $(10 \mathrm{mcg})$ and ceftazidime $(30 \mathrm{mcg})$ respectively. The degree of sensitivity was determined on the basis of zone of inhibition produced by the isolated bacteria after exposure to the particular antibiotics and after comparison with the minimum inhibitory concentration of the respective antibiotic. The results obtained on cultural properties of the bacteria and their antibiotic disc diffusion assays revealed in the present study were in correlation with the findings of earlier investigations. ${ }^{[11-18]}$

\section{Conclusion}

The present study revealed the presence of Staphylococcus spp. responsible for causing sub-clinical mastitis in dairy cattle. The bacteria was found to be sensitive to broad spectrum antibiotics which was reported and recommended to the T.V.C.C. for their administration in divided doses on alternate daily intervals in mixed preparations.

\section{ACKNOWLEDGEMENTS}

The authors are thankful to Hon'ble Dean and Management (Hony. Chairman and Secretary, Aastha Society, Sikar) of ARAWALI VETERINARY COLLEGE for providing the necessary facilities to conduct the research work.

\section{REFERENCES}

[1] Patnaik, S, Prasad, A. and Ganguly, S. (2013). Mastitis, an Infection of Cattle Udder: A Review. J. Chem. Biol. Physical Sci., Section-B [Biological Sciences]. 3(4): 2676-8.

[2] Paul, I., Isore, D.P., Joardar, S.N., Mukhopadhayay, S.K., Ganguly, S., Pal, S. (2013). Bacteriological investigation and antibiogram on Methicillin-resistant Staphylococcus aureus (MRSA) causing subclinical mastitis in dairy cattle population of West Bengal. Indian J. Comp. Microbiol. Immunol. Infect. Dis., 34(2): 56-9.

[3] Ganguly, S. (2014). A comprehensive and illustrious review on clinical and diagnostic aspects of Mastitis infection in high yielding lactating cows. World J. Pharma. Res., 3(9): 352-60.

[4] Wakchaure, R., Ganguly, S., Para P.A., Praveen, P.K., Qadri, K. (2015). Mastitis, an economically important disease affecting lactating ruminants: A Review. Chap. 15, pp. 199-212. In: New Dimensions in Microbiology [Eds. Dr. M.M. Abid Ali Khan (India), Dr. John K. Grandy (USA), Dr. Egamberdieva Dilfuza (Germany), Murataza Abid (India), Dr. Raaz K. Maheshwari (India), Dr. T.S. Naqvi (India)], Lenin Media, Delhi, India. ISBN 978-93-85160-84-4.

[5] Padhy, A., Sahu, A.R., Shekhar, S., Sahoo, S., Sahoo, A. and Dalai, N. (2015). Staphylococcus aureus: an emergent cause of bovine mastitis in India- a review. Int. J. Livest. Res., 5(2): 1-7. DOI 10.5455/ijlr.20150212093551

[6] Buxton, A. and Fraser, G. (1977). Animal Microbiology. Vol. 1. Blackwell Scientific Publications.

[7] Sinha, S.N. (2006). Focus on College Practical Microbiology. Part-I. Rita Book Agency, Kolkata, India.

[8] Ananthanarayan, R. and Paniker, C.K. Jayaram. (2009). Textbook of Microbiology. $8^{\text {th }}$ ed. Universities Press (India) Pvt. Ltd. Hyderabad, India. ISBN 9788173716744.

[9] Cruickshank, R., Duguid, J.P., Marmion, B.P. and Swain, R.H.A. (1975). Medical Microbiology. $12^{\text {th }}$ ed. Vol. II, Churchill Livingstone, London.

[10] Finegold, S.M. and Martin, M.J. (1982). Diagnostic Microbiology. $6^{\text {th }}$ ed. The C.V. Morsby Co., London.

[11] Ganguly, S., Padhy, A., Sahoo, S., Garg, S.L., Praveen, P.K., Wakchaure, R., Para, P.A., Sharma, S., Kumar, A., Pandey, A.K., Mahajan, T and Qadri, K. (2015). Bacteriological examination and antibiogram of milk sample of clinically infected dairy cow suffering from mastitis. Int. J. Medi. Microbiol. Trop. Dis., 1(1): 6-7.

[12] Ganguly, S., Padhy, A., Sahoo, S., Garg, S.L., Wakchaure, R., Praveen, P.K., Para, P.A., Mahajan, T., Qadri, K. and Sharma, R. (2016a). Antibiogram of milk sample of a farm maintained dairy cow suffering from mastitis followed by its clinical recovery. Int. J. Sci. Environ. Technol., 5(1): 148-51. 
[13] Ganguly, S. and Praveen, P.K. (2016b). Microbiological examination of milk samples from cow udder affected with chronic clinical mastitis. Int. J. Rec. Dev. Engg. Technol., 5(5): 1-2.

[14] Ganguly, S. (2016c). Bacteriological examination of cow milk samples collected from case of chronic clinical mastitis. Int. J. Rec. Dev. Engg. Technol., 5(6): 8-9.

[15] Kumar, M., Prasad, A., Tiwary, B.K. and Ganguly, S. (2010). Study on incidence of mastitis in cattle population of Ranchi (Jharkhand) under different dairy farm conditions. Livest. Line, 4(6): pp. 8.

[16] Patnaik, S., Prasad, A. and Ganguly, S. (2014). Biochemical characterization and antibiogram of Staphylococcal microorganisms associated with subclinical mastitis in lactating crossbred cows. Anim. Sci. Rep., 8(4): 123-9.

[17] Ganguly, S. and Wakchaure, R. (2016d). Bacteriological analysis of cow milk sample suspected of being affected with sub-clinical mastitis. Int. J. Engg. Innov. Technol., 6(3): 38-39 (2016d).

[18] Ganguly, S., Para, P.A. and Praveen, P.K. (2017). Bacteriological examination of cow milk samples suspected of clinical mastitis: A case study. Int. J. Pure Appl. Biosci., 5(1): 207-09. OI: http://dx.doi.org/10.18782/2320-7051.2518D 